\title{
Synthesis of thiophene and $N$-substituted thieno[3,2-d] pyrimidine derivatives as potent antitumor and antibacterial agents
}

\author{
HEND N. HAFEZ $Z^{1,2^{*}}$ \\ SULAIMAN A. ALSALAMAH ${ }^{3}$ \\ ABDEL-RHMAN B. A. EL-GAZZAR ${ }^{1,2}$ \\ ${ }^{1}$ Al-Imam Mohammad Ibn Saud Islamic \\ University (IMSIU) \\ Faculty of Science \\ Department of Chemistry \\ P.O. Box 90950 Riyadh 11623 \\ Kingdom of Saudi Arabia \\ ${ }^{2}$ Photochemistry Department \\ (Heterocyclic \& Nucleosides Unit) \\ National Research Centre, Dokki 12622 \\ Giza, Egypt \\ ${ }^{3}$ Al-Imam Mohammad Ibn Saud Islamic \\ University (IMSIU) \\ Faculty of Science \\ Biology Department (Microbiology Unit) \\ P.O. Box 90950 Riyadh 11623 \\ Kingdom of Saudi Arabia
}

\begin{abstract}
A novel series of carbamothioylamino-benzene-sulfonamidethiophene-carboxylates $4 \mathbf{a}-\mathbf{c}$ and thieno[3,2- $d$ ]pyrimidin-2yl-amino-benzene-sulfonamides $5 \mathbf{a}-\mathbf{c}$ were synthesized in a series of synthetic steps and were used as key intermediates for the synthesis of thienotriazolopyrimidine-benzene-sulfonamide derivatives 6a-c and 7a-c. Thieno[3,2- $d]$ pyrimidinones ( 8 and $\mathbf{9}$ ) were also prepared. Compound $\mathbf{9}$ was used as an intermediate for the synthesis of imidazole/1,2,4-triazole and tetrazine functionalized thieno[3,2- $d]$ pyrimidine derivatives (10-12). Pyrrole derivatives/pyrrolopyrimidine/pyrrolotriazolopyrimidine functionalized thiophenes (15-19) were also synthesized. Structures of the newly synthesized compounds were established by elemental analysis and spectral data. Most of the newly synthesized compounds were evaluated for their in vitro activity against three human tumor cell lines, namely, liver cancer (HepG-2), colon cancer (HT-29) and lung cancer (NCI-H460), using doxorubicin as standard. Compounds $16\left(G_{50}=0.02,0.04\right.$ and $0.06 \mu \mathrm{mol} \mathrm{L}{ }^{-1}$, resp. $)$ and $19 \mathrm{~b}\left(G I_{50}=0.02,0.03\right.$ and $0.05 \mu \mathrm{mol} \mathrm{L}^{-1}$, resp. $)$ showed higher activity against all cell lines than doxorubicin. Most of the compounds were also screened for antibacterial activity using ciprofloxacin as standard drug. Compounds $4 \mathrm{~b}$ and $6 \mathrm{~b}$, both containing benzenesulfonamide linked to $N-, \mathbf{1 0}$ bearing imidazole moiety, and $\mathbf{1 5}$ and $\mathbf{1 9 b}, \mathrm{c}$ with a thiophene-2-carboxylic acid chain, exhibited high activity against Gram-positive and Gram-negative bacteria.
\end{abstract}

Keywords: thieno[3,2- $d]$ pyrimidines, thieno[3,2- $d][1,2,4]$ triazolo[1,5-a]pyrimidines, anticancer, antibacterial

Thiophene derivatives are among the most important chemotherapeutic agents and are widely used $(1,2)$. Thienopyrimidines occupy a special position among condensed heterocyclic compounds. They have been widely employed due to their activities as antitumor (3, 4), antimetabolite (5), antiviral, anti-HIV-1 (6), antiproliferative (7), antimicrobial $(10,11)$, analgesic and anti-inflammatory $(12,13)$ agents, as well as kinase $(8)$ and phospho-

\footnotetext{
*Correspondence; e-mail: dr.hendhafez@yahoo.com
} 
diesterase IV inhibitors (9). Among these active compounds, thieno[3,2- $d$ ]pyrimidines have generated wide-spread interest due to their remarkable antitumor activities $(3,4,14)$. Thus, substituted thieno[3,2- $d$ ] pyrimidines exert pronounced activity as PI3K inhibitors (GDC-0941) and EGFR and VEGFR dual inhibitors, which are used in the treatment of cancers (15-17). As a part of our continuing program on the synthesis of antimicrobial and antitumor compounds, we have earlier reported on a series of heterocyclic moieties that have biological activities (11-13).

Furthermore, sulfonamide derivatives are an important class of compounds used as scaffolds in medicinal chemistry (11) in addition to triazole derivatives (18), showing antibacterial (19), antineoplastic (20) and antitubercular (21) activity. Recently, compounds bearing 1,2,4-triazole moieties have attracted great attention owing to their anticancer value $(22,23)$. The present work is an extension of our ongoing efforts towards the synthesis and evaluation of novel thiophenes bearing biologically active sulfonamide, pyrole, pyrrolopyrimidine derivatives, and thieno[3,2- $d$ ]pyrimidine derivatives containing 1,2,4-triazole moiety, as antitumor and antibacterial agents.

\section{EXPERIMENTAL}

An Electrothermal 9100 series digital melting point apparatus (Shimadzu, Japan) was used for all measurements of melting points. For microanalytical data, a Vario Elementar apparatus (Shimadzu) was used. Elemental analyses of all compounds were within $\pm 0.4 \%$ of theoretical values. IR spectra $(\mathrm{KBr})$ were recorded on a Perkin Elmer 1650 spectrometer (USA) while ${ }^{1} \mathrm{H}$ NMR and ${ }^{13} \mathrm{C}$ NMR spectra were recorded on JEOL EX-300 and JEOL ECA500 (Shimadzu) instruments, resp. Chemical shifts were expressed in ppm relative to $\mathrm{SiMe}_{4}$ as internal standard in DMSO- $d_{6}$ as solvent. For mass spectra recording, a $70 \mathrm{eV}$ Finnigan SSQ 7000 spectrometer (Thermo-Instrument System Incorporation, USA) was used. Purity of the compounds was checked by TLC using silica gel-coated aluminum plates (Merck, Germany). 3-Amino-5-(4-chlorophenyl)-thiophene-2-carboxylic acid (1) and other chemicals and solvents (Analar $\geq 99 \%$ ) were purchased from Sigma-Aldrich (USA). Ciprofloxacin and doxorubicin disks were supplied by the Pasteur Laboratory (Egypt).

\section{Syntheses}

Ethyl 3-amino-5-(4-chlorophenyl)-thiophene-2-carboxylate (2). - 3-Amino-5-(4chlorophenyl)-thiophene-2-carboxylic acid (1,15 g, $60 \mathrm{mmol})$ was suspended in $150 \mathrm{~mL}$ of absolute ethyl alcohol (99\%). Dry hydrogen chloride was passed through until the solution was saturated and became hot, then the reaction mixture was refluxed for $2 \mathrm{~h}$. When the reaction was complete, the solution was cooled and the mixture was diluted with 200 $\mathrm{mL}$ of water and made alkaline by sodium carbonate solution. A solid product crystallized from ethanol as white crystals.

Ethyl 5-(4-chlorophenyl)-3-isothiocyanatothiophene-2-carboxylate (3). - A mixture of compound $2(2.81 \mathrm{~g}, 10 \mathrm{mmol})$ and thiophosgene $(1.14 \mathrm{~mL}, 10 \mathrm{mmol})$ in dry chloroform $(25 \mathrm{~mL})$ was stirred under reflux for $6 \mathrm{~h}$. The solvent was evaporated and the solid obtained was recrystallized from ethanol as a deep yellow solid. 
H. N. Hafez et al:: Synthesis of thiophene and $N$-substituted thieno[3,2- $d$ ]pyrimidine derivatives as potent antitumor and antibacterial agents, Acta Pharm. 67 (2017) 275-292.

Table I. Physical and analytical data of newly synthesized compounds

\begin{tabular}{|c|c|c|c|c|c|c|c|c|c|}
\hline \multirow{3}{*}{$\frac{\text { Compd. }}{2}$} & \multirow{3}{*}{$\begin{array}{c}\text { Mol. formula } \\
\left(M_{\mathrm{r}}\right)\end{array}$} & \multirow{3}{*}{$\begin{array}{c}\begin{array}{c}\text { M. p. } \\
\left({ }^{\circ} \mathrm{C}\right)\end{array} \\
108-110\end{array}$} & \multirow{3}{*}{$\begin{array}{c}\begin{array}{c}\text { Yield } \\
(\%)\end{array} \\
65\end{array}$} & \multicolumn{6}{|c|}{ Analysis (calcd./found \%) } \\
\hline & & & & \multicolumn{2}{|c|}{ C } & \multicolumn{2}{|c|}{$\mathrm{H}$} & \multicolumn{2}{|c|}{$\mathrm{N}$} \\
\hline & & & & 55.42 & 55.40 & 4.29 & 4.28 & 4.97 & 4.94 \\
\hline 3 & $\mathrm{C}_{14} \mathrm{H}_{10} \mathrm{ClNO}_{2} \mathrm{~S}_{2}(323.8)$ & $165-167$ & 70 & 51.93 & 51.90 & 3.11 & 3.09 & 4.33 & 4.32 \\
\hline $4 a$ & $\mathrm{C}_{21} \mathrm{H}_{20} \mathrm{ClN}_{5} \mathrm{O}_{4} \mathrm{~S}_{3}(538)$ & $210-212$ & 60 & 46.88 & 46.86 & 3.75 & 3.74 & 13.00 & 13.02 \\
\hline $4 b$ & $\mathrm{C}_{26} \mathrm{H}_{24} \mathrm{ClN}_{5} \mathrm{O}_{6} \mathrm{~S}_{3}(634.1)$ & $230-232$ & 63 & 49.24 & 49.22 & 3.81 & 3.79 & 11.04 & 11.03 \\
\hline $4 c$ & $\mathrm{C}_{25} \mathrm{H}_{23} \mathrm{ClN}_{4} \mathrm{O}_{5} \mathrm{~S}_{3}(591.1)$ & $238-240$ & 70 & 50.80 & 50.78 & 9.48 & 9.45 & 3.92 & 3.90 \\
\hline $5 a$ & $\mathrm{C}_{19} \mathrm{H}_{16} \mathrm{ClN}_{7} \mathrm{O}_{3} \mathrm{~S}_{2}$ (489.9) & $254-256$ & 83 & 46.58 & 46.55 & 3.29 & 3.25 & 20.01 & 19.98 \\
\hline $5 b$ & $\mathrm{C}_{24} \mathrm{H}_{20} \mathrm{ClN}_{7} \mathrm{O}_{5} \mathrm{~S}_{2}(586)$ & $268-270$ & 70 & 49.19 & 49.16 & 3.44 & 3.42 & 16.70 & 16.73 \\
\hline $5 c$ & $\mathrm{C}_{23} \mathrm{H}_{21} \mathrm{ClN}_{6} \mathrm{O}_{4} \mathrm{~S}_{2}(545)$ & $282-284$ & 60 & 50.68 & 50.64 & 3.88 & 3.86 & 15.42 & 15.40 \\
\hline $6 a$ & $\mathrm{C}_{26} \mathrm{H}_{17} \mathrm{ClFN}_{7} \mathrm{O}_{3} \mathrm{~S}_{2}(594)$ & $>300$ & 62 & 52.57 & 52.53 & 2.88 & 2.86 & 16.51 & 16.48 \\
\hline $6 b$ & $\mathrm{C}_{31} \mathrm{H}_{21} \mathrm{ClFN}_{7} \mathrm{O}_{5} \mathrm{~S}_{2}(690.1)$ & $>300$ & 65 & 53.95 & 53.91 & 3.07 & 3.05 & 14.21 & 14.18 \\
\hline $6 c$ & $\mathrm{C}_{30} \mathrm{H}_{20} \mathrm{ClFN}_{6} \mathrm{O}_{4} \mathrm{~S}_{2}(647.1)$ & $>300$ & 66 & 55.68 & 55.64 & 3.12 & 3.10 & 12.99 & 12.95 \\
\hline $7 a$ & $\mathrm{C}_{20} \mathrm{H}_{14} \mathrm{ClN}_{7} \mathrm{O}_{3} \mathrm{~S}_{2}(499.9)$ & $218-220$ & 73 & 48.05 & 48.01 & 2.82 & 2.80 & 19.61 & 19.58 \\
\hline $7 \mathrm{~b}$ & $\mathrm{C}_{25} \mathrm{H}_{18} \mathrm{ClN}_{7} \mathrm{O}_{5} \mathrm{~S}_{2}(596)$ & $211-213$ & 59 & 50.38 & 50.34 & 3.04 & 3.02 & 16.45 & 16.42 \\
\hline $7 \mathrm{c}$ & $\mathrm{C}_{24} \mathrm{H}_{17} \mathrm{ClN}_{6} \mathrm{O}_{4} \mathrm{~S}_{2}(553)$ & $234-236$ & 66 & 52.12 & 52.10 & 3.10 & 3.07 & 15.20 & 15.16 \\
\hline 8 & $\mathrm{C}_{19} \mathrm{H}_{13} \mathrm{ClN}_{2} \mathrm{OS}(352.8)$ & $230-232$ & 60 & 64.68 & 64.64 & 3.71 & 3.69 & 7.94 & 7.92 \\
\hline 9 & $\mathrm{C}_{12} \mathrm{H}_{8} \mathrm{ClN}_{3} \mathrm{OS}(277.7$ ) & $225-227$ & 75 & 51.90 & 51.87 & 2.90 & 2.88 & 15.13 & 15.10 \\
\hline 10 & $\mathrm{C}_{28} \mathrm{H}_{17} \mathrm{ClN}_{4} \mathrm{O}_{2} \mathrm{~S}$ (508.9) & $253-255$ & 66 & 66.07 & 66.04 & 3.37 & 3.35 & 11.01 & 10.99 \\
\hline 11 & $\mathrm{C}_{13} \mathrm{H}_{7} \mathrm{ClN}_{4} \mathrm{~S}_{2}$ (318.8) & $289-291$ & 86 & 48.98 & 48.95 & 2.21 & 2.18 & 17.57 & 17.55 \\
\hline 12 & $\mathrm{C}_{24} \mathrm{H}_{12} \mathrm{Cl}_{2} \mathrm{~N}_{6} \mathrm{~S}_{2}$ (519.4) & $>330$ & 64 & 55.50 & 55.48 & 2.33 & 2.30 & 16.18 & 16.16 \\
\hline 13 & $\mathrm{C}_{12} \mathrm{H}_{8} \mathrm{ClN}_{3} \mathrm{~S}_{2}$ (293.7) & $262-264$ & 75 & 49.06 & 49.02 & 2.74 & 2.72 & 14.30 & 14.27 \\
\hline 14 & $\mathrm{C}_{19} \mathrm{H}_{14} \mathrm{ClNO}_{3} \mathrm{~S}$ (371.8) & $208-210$ & 75 & 61.37 & 61.34 & 3.79 & 3.75 & 3.77 & 3.73 \\
\hline 15 & $\mathrm{C}_{22} \mathrm{H}_{14} \mathrm{ClN}_{3} \mathrm{O}_{2} \mathrm{~S}(419.8)$ & $180-182$ & 70 & 62.93 & 62.90 & 3.36 & 3.34 & 10.01 & 9.98 \\
\hline 16 & $\mathrm{C}_{24} \mathrm{H}_{16} \mathrm{ClN}_{3} \mathrm{O}_{3} \mathrm{~S}(461.9)$ & $234-236$ & 65 & 62.40 & 62.38 & 3.49 & 3.44 & 9.10 & 9.07 \\
\hline 17 & $\mathrm{C}_{26} \mathrm{H}_{16} \mathrm{ClN}_{3} \mathrm{O}_{4} \mathrm{~S}$ (501.9) & $250-252$ & 76 & 62.21 & 62.18 & 3.21 & 3.19 & 8.37 & 8.33 \\
\hline 18 & $\mathrm{C}_{25} \mathrm{H}_{18} \mathrm{ClN}_{3} \mathrm{O}_{3} \mathrm{~S}(475.9)$ & $238-240$ & 65 & 63.09 & 63.05 & 3.81 & 3.79 & 8.83 & 8.80 \\
\hline $19 a$ & $\mathrm{C}_{30} \mathrm{H}_{18} \mathrm{ClN}_{5} \mathrm{O}_{2} \mathrm{~S}(548)$ & $266-268$ & 60 & 65.75 & 65.72 & 3.31 & 3.29 & 12.78 & 12.74 \\
\hline $19 b$ & $\mathrm{C}_{30} \mathrm{H}_{17} \mathrm{Cl}_{2} \mathrm{~N}_{5} \mathrm{O}_{2} \mathrm{~S}$ (582.4) & $284-286$ & 73 & 61.86 & 61.82 & 2.94 & 2.91 & 12.02 & 12.00 \\
\hline $19 \mathrm{c}$ & $\mathrm{C}_{31} \mathrm{H}_{20} \mathrm{ClN}_{5} \mathrm{O}_{3} \mathrm{~S}(578.0)$ & $279-281$ & 68 & 64.41 & 64.38 & 3.49 & 3.46 & 12.12 & 12.09 \\
\hline
\end{tabular}

Ethyl-5-(4-chlorophenyl)-3-[N-(substituted) 4-(carbamothioyl)amino-benzenesulfonamide] thiophene-2-carboxylate derivatives $(\mathbf{a} \boldsymbol{a}-\boldsymbol{c})$. General procedure. - A mixture of compound 3 (3.24 $\mathrm{g}, 10 \mathrm{mmol}$ ) and $0.01 \mathrm{~mol}$ of the appropriate sulfa drug (sulfaguanidine, 2,6-dimethoxysulfadiazine or 3,4-dimethylsulfaiso-oxazole) in DMF (30 mL) was stirred under reflux for $5 \mathrm{~h}$. The reaction mixture was poured onto ice water and the obtained product was recrystallized from dioxane to give compounds $4 \mathbf{a}-\mathbf{c}$. The following compounds were prepared: 
ethyl 5-(4-chlorophenyl)-3-[N-carbamimidoyl-4-(carbamothioyl)amino-benzene-sulfonamide]thiophene-2-carboxylate (4a), ethyl 5-(4-chlorophenyl)-3-[N-(2,6-dimethoxypyrimidin-4-yl)-4-(carbamothioyl) amino-benzenesulfonamide] thiophene-2-carboxylate (4b) and ethyl 5-(4-chlorophenyl)-3-[N-(3,4-dimethyl-1,2-oxazol-5-yl)-4-(methylcarbamothioyl)amino-benzenesulfonamide]thiophene-2-carboxylate (4c).

4-\{[3-Amino-6-(4-chlorophenyl)-4-oxo-3,4-dihydrothieno[3,2-d]pyrimidin-2-yl]-amino-Nsubstituted benzenesulfonamide derivatives $(5 a-c)$. General procedure. - A mixture of $4 \mathbf{a}-\mathrm{c}(10$ $\mathrm{mmol})$ and hydrazine hydrate $(10 \mathrm{~mL})$ in butanol $(30 \mathrm{~mL})$ was refluxed for $5 \mathrm{~h}$. After cooling, the reaction mixture was poured onto ice water and the solid obtained was recrystallized from dioxane to give 5a-c. The following compounds were prepared: 4-\{[3-amino-6-(4chlorophenyl)-4-oxo-3,4-dihydrothieno[3,2-d]pyrimidin-2-yl]amino\}- $N$-carbamimidoylbenzenesulfonamide (5a), 4-\{[3-amino-6-(4-chlorophenyl)-4-oxo-3,4-dihydrothieno[3,2- $d]$ pyrimidin-2-yl]amino\}- $N$-(2,6-dimethoxypyrimidin-4-yl)benzenesulfonamide $\quad(5 \mathbf{b})$ and 4-\{[3-amino-6-(4-chlorophenyl)-4-oxo-3,4-dihydrothieno[3,2-d]pyrimidin-2-yl]amino\}-N(3,4-dimethyl-1,2-oxazol-5-yl) benzene sulfonamide (5c).

7-(4-Chlorophenyl)-2-(4-fluorophenyl)-1-(N-substituted)benzenesulfonamide thieno[3,2-d] $[1,2,4]$ triazolo[1,5-a]pyrimidine-5(1H)-thione $(6 \boldsymbol{a}-\boldsymbol{c})$. General procedure. - A mixture of $5 \boldsymbol{a}-\boldsymbol{c}(10$ $\mathrm{mmol})$ and 4-fluorobenzaldehyde $(1.24 \mathrm{~g}, 10 \mathrm{mmol})$ in glacial acetic acid $(20 \mathrm{~mL})$ containing fused sodium acetate $(0.5 \mathrm{~g})$ was heated under reflux for $6 \mathrm{~h}$. The solvent was concentrated and the residue was recrystallized from dioxane to give $6 \mathbf{a}-\mathbf{c}$. The following compounds were prepared: 7-(4-chlorophenyl)-2-(4-fluorophenyl)-1-( $N$-carbamimidoylbenzenesulfonamide) thieno[3,2- $d][1,2,4]$ triazolo[1,5-a]pyrimidine-5(1H)-thione (6a), 7-(4-chlorophenyl)-2(4-fluorophenyl)-1-( $N$-(2,6-dimethoxypyrimidin-4-yl) benzenesulfonamide thieno[3,2- $d$ ] $[1,2,4]$ triazolo[ $1,5-a]$ pyrimidine-5 $(1 H)$-thione $(\mathbf{6 b})$ and 7-(4-chlorophenyl)-2-(4-fluorophenyl)1-(N-(3,4-dimethyl-1,2-oxazol-5-yl) benzenesulfonamide thieno[3,2-d][1,2,4]triazolo[1,5- $a]$ pyrimidine-5(1H)-thione $(\mathbf{6 c})$.

$\mathrm{N}$-substituted-4-[7-(4-chlorophenyl)-5-oxothieno[3,2-d][1,2,4] triazolo[1,5-a]pyrimidine1(5H)-yl)]-benzenesulfonamide $(7 \boldsymbol{a}-\mathrm{c})$. General procedure. - A solution of compound 5a-c (10 $\mathrm{mmol})$ in formic acid $(20 \mathrm{~mL})$ was heated under reflux for $10 \mathrm{~h}$. The solvent was evaporated under vacuum and the residue was recrystallized from ethanol to give 7a-c. The following compounds were prepared: $N$-carbamimidoyl-4-[7-(4-chlorophenyl)-5-oxothieno[3,2- $d$ ] [1,2,4]triazolo[1,5-a] pyrimidine-1(5H)-yl)]-benzenesulfonamide (7a), 4-[7-(4-chlorophenyl)5-oxothieno[3,2- $d][1,2,4]$ triazolo [1,5-a]pyrimidine-1(5H)-yl)]-(1-(N-2,6-dimethoxypyrimidin-4-yl)-benzenesulfonamide (7b) and 4-[7-(4-chlorophenyl)-5-oxothieno[3,2-d][1,2,4] triazolo[1,5-a] pyrimidine-1(5H)-yl)]-(1-(N-(3,4-dimethyl[1,2]isooxazol-5-yl)-benzenesulfonamide (7c).

3-Benzyl-6-(4-chlorophenyl)-thieno[3,2-d]pyrimidin-4(2H)-one (8). - A mixture of compound $2(2.81 \mathrm{~g}, 10 \mathrm{mmol})$ and benzylamine $(1.07 \mathrm{~g}, 10 \mathrm{mmol})$ in decalin $(2.7 \mathrm{~mL}, 20 \mathrm{mmol})$ and triethylorthoformate $(15 \mathrm{~mL})$ was refluxed for $16 \mathrm{~h}$, the reaction mixture was cooled and filtered, the obtained solid was crystallized from ethanol as a pale-yellow powder.

3-Amino-6-(4-chlorophenyl)-thieno[3,2-d]pyrimidin-4(3H)-one (9). - A mixture of compound $2(2.81 \mathrm{~g}, 10 \mathrm{mmol})$, hydrazine hydrate $(98 \%, 2 \mathrm{~mL})$ in absolute ethanol and triethylorthoformate $(10 \mathrm{~mL})$ was refluxed for $10 \mathrm{~h}$, the reaction mixture was cooled and filtered. The obtained solid was crystallized from ethanol as a pale-brown powder. 
6-(4-Chlorophenyl)-3-(5-benzylidene-2-phenyl-3,5-dihydro-4H-imidazol-4-one-3-yl) thieno[3,2-d]pyrimidin-4(3H)-one (10). - A mixture of compound 9 (2.78 g, $10 \mathrm{mmol})$, and 4-benzylidene-2-phenyl-4H-oxazol-5-one $(2.49 \mathrm{~g}, 10 \mathrm{mmol})$ in glacial acetic acid $(20 \mathrm{~mL})$ containing fused sodium acetate $(2 \mathrm{~g})$ was refluxed for $5 \mathrm{~h}$. The reaction mixture was cooled and then poured onto cold water, the solid obtained was crystallized from DMF as a white powder.

8-(4-Chlorophenyl)-thieno[2,3-e][1,2,4]triazolo[1,5-c]pyrimidine-2(3H)-thione (11). - A mixture of compound $9(2.78 \mathrm{~g}, 10 \mathrm{mmol})$ and thiourea $(0.76 \mathrm{~g}, 10 \mathrm{mmol})$ was fused over an oil bath at $220{ }^{\circ} \mathrm{C}$ for $30 \mathrm{~min}$. The solid thus obtained was crystallized from ethanol as a yellow powder.

Bis-6,6'-(4-dichlorophenyl)-thieno[2,3-e]pyrimido[3,4-c][1,2,4,5]tetrazine (12) (24). - A mixture of compound $9(2.78 \mathrm{~g}, 10 \mathrm{mmol})$ and phosphorous pentasulfide $(2.66 \mathrm{~g}, 12 \mathrm{mmol})$ in pyridine $(20 \mathrm{~mL})$ was refluxed for $12 \mathrm{~h}$, the reaction mixture was concentrated and allowed to cool. The solid obtained was crystallized from ethanol as a white powder.

3-Amino-6-(4-chlorophenyl)-thieno[3,2-d]pyrimidin-4(3H)-thione (13). - A mixture of 9 $(2.78 \mathrm{~g}, 10 \mathrm{mmol})$ and phosphorous pentasulfide $(2.66 \mathrm{~g}, 12 \mathrm{mmol})$ in xylene $(25 \mathrm{~mL})$ was heated under reflux for $5 \mathrm{~h}$. The reaction mixture was hot filtered, the solid that separated from the filtrate crystallized from ethanol as a yellow powder.

5-(4-Chlorophenyl)-3-[(2-oxo-2-phenylethyl)-amino]thiophene-2-carboxylic acid (14). - A mixture of thiophene derivative $\mathbf{1}(2.53 \mathrm{~g}, 10 \mathrm{mmol})$ and phenacyl bromide $(1.99 \mathrm{~g}, 10 \mathrm{mmol})$ was refluxed in ethanol for $3 \mathrm{~h}$. The solid obtained was filtered and crystallized from dioxane to give $\mathbf{1 4}$ as an orange powder.

3-(2-Amino-3-cyano-4-phenyl-1H-pyrrol-1-yl)-5-(4-chlorophenyl)-thiophene-2-carboxylic acid (15). - A mixture of $14(3.71 \mathrm{~g}, 10 \mathrm{mmol})$ and malononotrile $(0.66 \mathrm{~g}, 10 \mathrm{mmol})$ in ethanol $(30 \mathrm{~mL})$ containing sodium ethoxide $(0.5 \mathrm{~g})$ was refluxed for $5 \mathrm{~h}$, the reaction mixture was cooled and acidified with dil. $\mathrm{HCl}$. The solid obtained was recrystallized from dioxane to give 15 as pale-yellow crystals.

5-(4-Chlorophenyl)-3-(2-methyl-4-oxo-5-phenyl-3,4-dihydro-7H-pyrrolo[2,3-d]pyrimidine7-yl)-thiophene-2-carboxylic acid (16). - A solution of $\mathbf{1 5}$ in acetic anhydride (30 mL) was refluxed for $8 \mathrm{~h}$, the reaction mixture was concentrated under reduced pressure and the solid obtained was crystallized from ethanol to give $\mathbf{1 6}$ as a white powder.

3-(3-Cyano-2-(2,5-dioxopyrrolidin-1-yl)-4-phenyl-1H-pyrrol-1-yl)-5-(4-chlorophenyl)-thiophene-2-carboxylic acid (17). - A mixture of $15(4.19 \mathrm{~g}, 10 \mathrm{mmol})$ and succinic anhydride (1.10 $\mathrm{g}, 10 \mathrm{mmol}$ ) was fused at $220^{\circ} \mathrm{C}$ in an oil bath for $15 \mathrm{~min}$. The reaction mixture was triturated with ethanol and the solid obtained was crystallized from methanol to give $\mathbf{1 7}$ as brown crystals.

3-(3-Cyano-2-amino(ethoxymethylene)-4-phenyl-1H-pyrrol-1-yl)-5-(4-chlorophenyl)-thiophene-2-carboxylic acid (18). - To a mixture of triethylorthoformate $(1.48 \mathrm{~g}, 10 \mathrm{mmol})$ and acetic anhydride (20 mL), compound $15(4.19 \mathrm{~g}, 10 \mathrm{mmol})$ was added and the reaction mixture was refluxed for $5 \mathrm{~h}$. The solvent was removed under reduced pressure and the separated solid was recrystallized from dioxane, to give $\mathbf{1 8}$ as a yellow powder.

5-(4-Chlorophenyl)-\{3-(4-substitutedphenyl)-9-phenyl-7H-pyrrolo[3,2-e][1,2,4] triazolo[4,3c]-pyrimidin-7-yl\}- thiophene-2-carboxylic acid $(\mathbf{1 9 a}-\mathbf{c})$. General procedure. - To a solution of $\mathbf{1 8}$ ( $4.75 \mathrm{~g}, 10 \mathrm{mmol})$ in absolute ethanol $(50 \mathrm{~mL})$, hydrazide derivative $(10 \mathrm{mmol})$ was added. The reaction mixture was refluxed for $4 \mathrm{~h}$, concentrated, cooled and the solid product that 


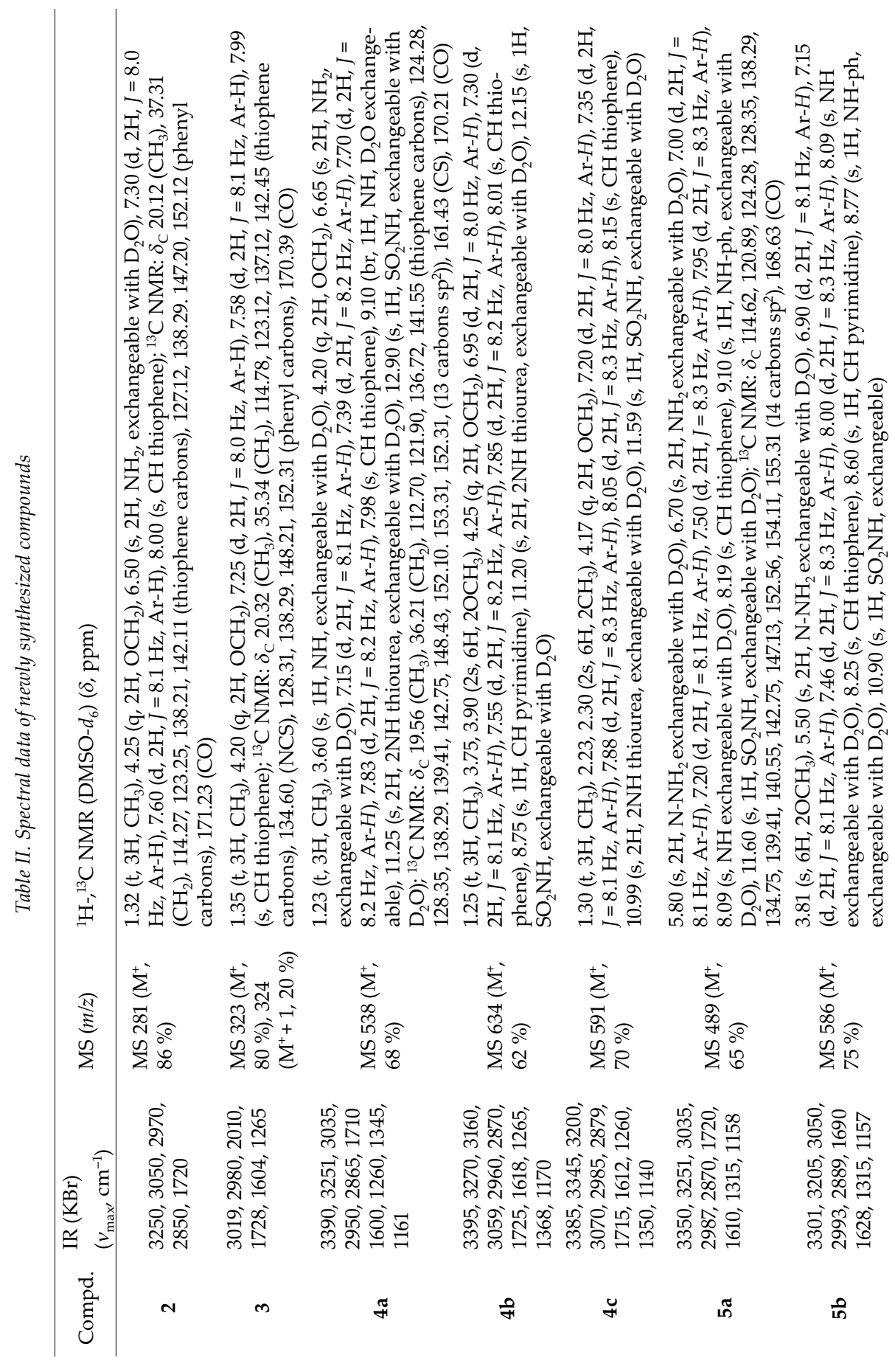




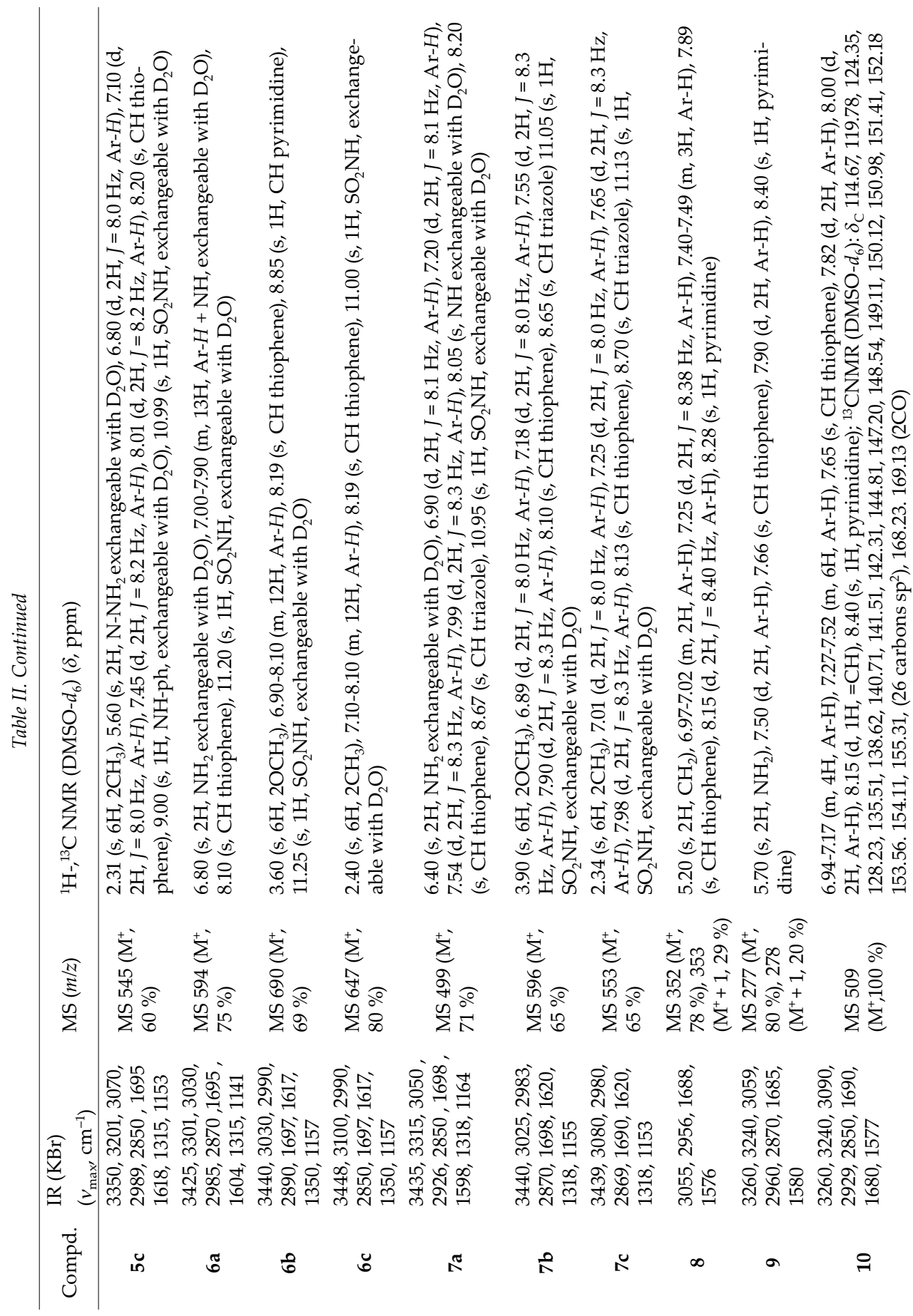




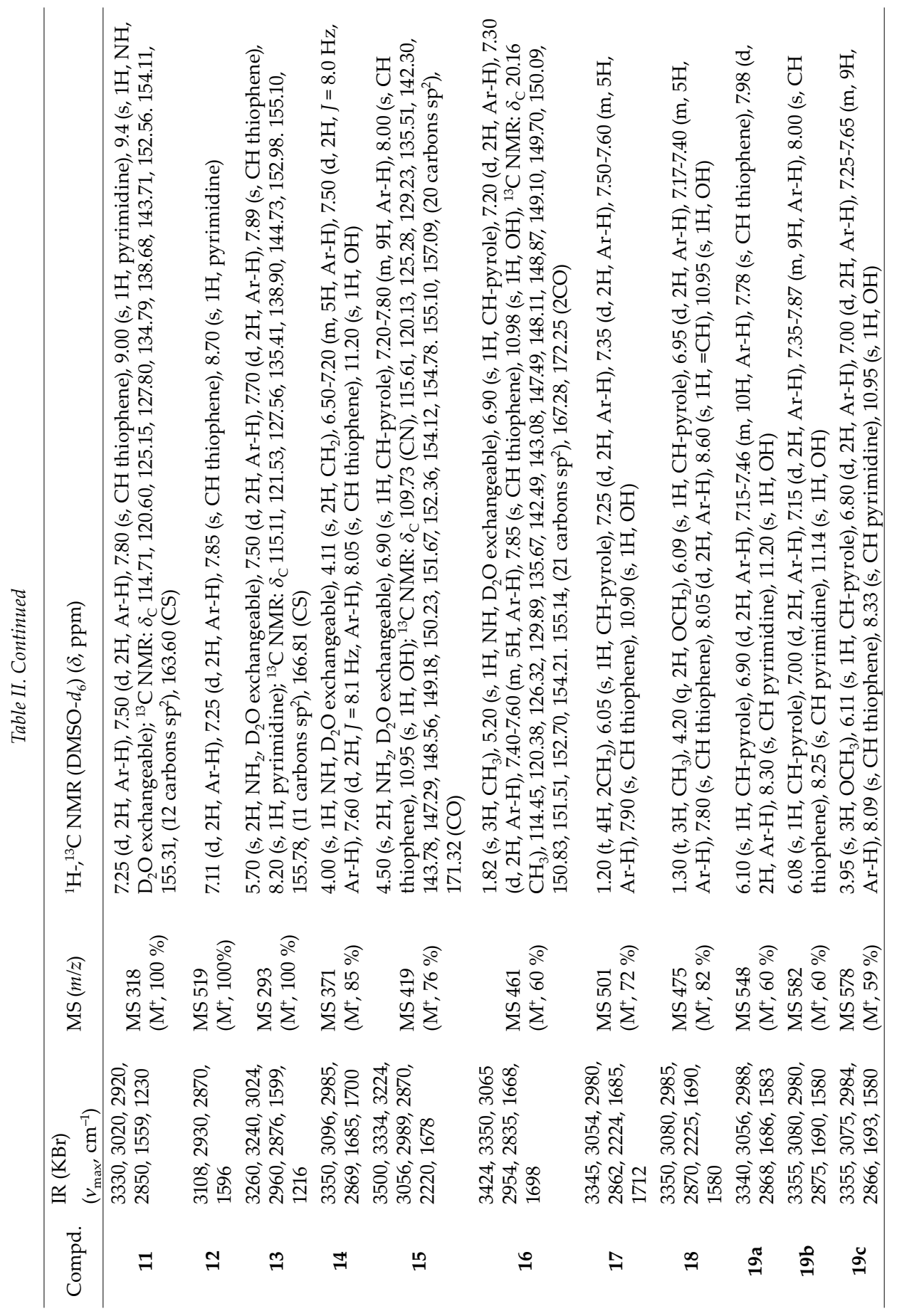


separated was filtered off and recrystallized from appropriate solvent to give 19a-c. The following compounds were prepared: 5-(4-chlorophenyl)-3-(3,9-diphenyl-7H-pyrrolo[3,2-e] [1,2,4] triazolo[4,3-c]-pyrimidin-7-yl)-thiophene-2-carboxylic acid (19a), 5-(4-chlorophenyl)\{3-(4-chlorophenyl)-9-phenyl-7H-pyrrolo[3,2-e][1,2,4]triazolo[4,3-c]-pyrimidin-7-yl\}-thiophene-2-carboxylic acid (19b) and 5-(4-chlorophenyl)-\{3-(4-methoxyphenyl)-9-phenyl-7Hpyrrolo[3,2-e][1,2,4]triazolo[4,3-c]-pyrimidin-7-yl\}-thiophene-2-carboxylic acid (19c).

\section{Biological screening}

Antitumor activity. - The majority of newly synthesized compounds were tested for in vitro anticancer activity against three human cancer cell lines [liver cancer (HepG-2), colon cancer (HT29) and lung cancer (NCI-H460)] using the MTT assay. The three human cancer cell lines were provided by the National Cancer Institute (NCI, Cairo, Egypt). Their growth as a monolayer was maintained in RPMI-1640 medium supplemented with $5 \%$ heat inactivated FBS (fetal bovine serum), $2 \mathrm{mmol} \mathrm{L}^{-1}$ glutamine and antibiotics (penicillin $100 \mathrm{U} \mathrm{mL}^{-1}$, streptomycin $100 \mu \mathrm{g} \mathrm{mL}-1$ ) at $37^{\circ} \mathrm{C}$. Exponentially growing cells were obtained by plating $1.5 \times 10^{5}$ cells $\mathrm{mL}^{-1}$, followed by $24-\mathrm{h}$ incubation. The effect of the solvent DMSO on cell growth was evaluated by exposing untreated control cells to the maximum concentration of DMSO $(0.5 \%)$ used in each assay. Effects of the compounds on in vitro growth of human tumor cell lines was evaluated according to the procedure of the National Cancer Institute (NCI, USA), using sulforhodamine B as protein binding dye to assess cell growth (25). Cells growing exponentially in 96-well plates were then exposed for $48 \mathrm{~h}$ to five serial concentrations of each compound, starting from a maximum concentration of $150 \mu \mathrm{mol} \mathrm{L}{ }^{-1}$. After this exposure period, adherent cells were fixed, washed and stained. The bound stain was solubilized, the absorbance was measured and the growth inhibition of $50 \%\left(G I_{50}\right)$ was calculated (26). Doxorubicin was used as a reference compound (Table III).

Antibacterial activity. - Antibacterial activity of the newly synthesized compounds was tested in vitro against the Gram-positive bacteria Staphylococcus aureus ATCC-1096, Streptococcus bovis ATCC-1030 and Gram-negative bacteria Chlamydia pneumoniae ATCC-1416 and Salmonella typhi ATCC 2453. All microorganisms were purchased from the American Type Culture Collection (Manassas, USA). The compounds were dissolved in DMSO and preliminarily tested for antibacterial activity using the agar disk diffusion technique (27), microplate-wells ( $1 \mathrm{~cm}$ in diameter) and a solution of $100 \mu \mathrm{g} \mathrm{mL}^{-1}$ of the test compound. Compound-impregnated disks were placed on an agar plate containing a standard suspension of microorganisms. The plate was incubated for $24 \mathrm{~h}$ at $37^{\circ} \mathrm{C}$. Diameters of the zones of inhibition were measured with calipers or automated scanners and were compared to those of the standards (data not shown). Ciprofloxacin $\left(50 \mu \mathrm{g} \mathrm{mL}^{-1}, 150.9 \mu \mathrm{mol} \mathrm{L}^{-1}\right)$ was used as a reference drug.

For determination of the minimum inhibitory concentration $(M I C)$ by the serial plate dilution method (28), $5 \mathrm{mg}$ of each test compound was dissolved in $1 \mathrm{~mL}$ of DMSO to prepare a stock solution. Serial dilutions were prepared from the stock solution. The plates were incubated at $37^{\circ} \mathrm{C}$ for $24 \mathrm{~h}$. MIC was the lowest concentration (expressed in $\mu \mathrm{mol} \mathrm{L}^{-1}$ ) of the test compound that resulted in no visible growth on the plates. DMSO was used as a solvent control to ensure that the solvent had no effect on bacterial growth. Results of antibacterial activities are summarized in Table IV. 
H. N. Hafez et al.: Synthesis of thiophene and $N$-substituted thieno[3,2- $d$ ]pyrimidine derivatives as potent antitumor and antibacterial agents, Acta Pharm. 67 (2017) 275-292.

Table III. Effects of synthesized compounds on the growth of three human tumor cell lines

\begin{tabular}{|c|c|c|c|}
\hline \multirow[t]{2}{*}{ Compd. } & \multicolumn{3}{|c|}{$G I_{50}(\mu \mathrm{mol} \mathrm{L}-1)$} \\
\hline & HepG-2 & HT29 & NCI-H460 \\
\hline $4 a$ & $10.0 \pm 4.2$ & $6.4 \pm 2.6$ & $8.4 \pm 1.5$ \\
\hline $4 b$ & $0.06 \pm 0.004$ & $0.09 \pm 0.03$ & $0.1 \pm 0.08$ \\
\hline $4 c$ & $18.5 \pm 3.8$ & $22.0 \pm 2.6$ & $20.0 \pm 4.6$ \\
\hline $5 a$ & $2.6 \pm 0.2$ & $2.2 \pm 0.4$ & $1.6 \pm 0.8$ \\
\hline $5 b$ & $1.2 \pm 0.2$ & $2.6 \pm 0.6$ & $3.2 \pm 0.6$ \\
\hline $5 c$ & $4.05 \pm 0.2$ & $4.2 \pm 0.2$ & $4.8 \pm 0.4$ \\
\hline $6 a$ & $4.02 \pm 0.2$ & $4.8 \pm 0.4$ & $4.6 \pm 0.2$ \\
\hline $6 b$ & $0.5 \pm 0.01$ & $0.8 \pm 0.02$ & $0.4 \pm 0.02$ \\
\hline $6 c$ & $5.8 \pm 0.8$ & $6.5 \pm 0.4$ & $4.8 \pm 0.4$ \\
\hline 8 & $8.2 \pm 1.9$ & $6.9 \pm 0.4$ & $8.6 \pm 2.6$ \\
\hline 9 & $10.6 \pm 1.5$ & $8.4 \pm 2.6$ & $12.5 \pm 4.2$ \\
\hline 10 & $4.4 \pm 0.4$ & $4.05 \pm 0.2$ & $4.6 \pm 0.2$ \\
\hline 11 & $2.5 \pm 0.6$ & $3.2 \pm 0.4$ & $3.01 \pm 0.2$ \\
\hline 12 & $22.5 \pm 3.6$ & $20.6 \pm 2.6$ & $16.0 \pm 4.6$ \\
\hline 14 & $6.05 \pm 0.2$ & $8.0 \pm 0.8$ & $4.8 \pm 0.4$ \\
\hline 15 & $0.06 \pm 0.008$ & $0.08 \pm 0.02$ & $0.1 \pm 0.02$ \\
\hline 16 & $0.02 \pm 0.008$ & $0.04 \pm 0.01$ & $0.06 \pm 0.04$ \\
\hline 17 & $4.4 \pm 0.2$ & $8.9 \pm 0.8$ & $6.5 \pm 0.2$ \\
\hline 18 & $12.4 \pm 4.4$ & $8.5 \pm 2.6$ & $8.7 \pm 1.5$ \\
\hline $19 a$ & $8.9 \pm 0.8$ & $6.6 \pm 0.4$ & $6.0 \pm 0.6$ \\
\hline $19 b$ & $0.02 \pm 0.008$ & $0.03 \pm 0.007$ & $0.05 \pm 0.02$ \\
\hline $19 c$ & $2.4 \pm 0.6$ & $1.6 \pm 0.8$ & $4.6 \pm 0.2$ \\
\hline Doxorubicin & $0.04 \pm 0.008$ & $0.05 \pm 0.007$ & $0.09 \pm 0.007$ \\
\hline
\end{tabular}

Results are given as concentrations that were able to cause $50 \%$ cell growth inhibition $\left(G I_{50}\right)$ after continuous exposure for $48 \mathrm{~h}$. Mean \pm SEM of three independent experiments performed in duplicate. 
H. N. Hafez et al.: Synthesis of thiophene and $N$-substituted thieno[3,2- $d$ ]pyrimidine derivatives as potent antitumor and antibacterial agents, Acta Pharm. 67 (2017) 275-292.

Table IV. Minimum inhibitory concentration (MIC, $\mu \mathrm{mol} \mathrm{L}^{-1}$ ) of newly synthesized compounds

\begin{tabular}{|c|c|c|c|c|}
\hline \multicolumn{5}{|c|}{ Microorganism } \\
\hline \multirow[b]{2}{*}{ Compd. } & \multicolumn{2}{|c|}{ Gram-positive } & \multicolumn{2}{|l|}{ Gram-negative } \\
\hline & S. aureus & S. bovis & C. pneumoniae & S. typhi \\
\hline $4 a$ & 8 & 4 & 5 & 5 \\
\hline $4 b$ & 2 & 3 & 3 & 7 \\
\hline $4 c$ & 12 & 10 & 4 & 4 \\
\hline $5 a$ & 11 & 10 & 10 & 12 \\
\hline $5 b$ & 8 & 8 & 10 & 11 \\
\hline $5 c$ & 9 & 12 & 8 & 8 \\
\hline $6 a$ & 8 & 6 & 6 & 6 \\
\hline $6 b$ & 1 & 2 & 2 & 3 \\
\hline $6 c$ & 10 & 6 & 8 & 8 \\
\hline 8 & 10 & 8 & 8 & 6 \\
\hline 9 & 6 & 6 & 8 & 8 \\
\hline 10 & 2 & 3 & 4 & 4 \\
\hline 11 & 5 & 4 & 5 & 5 \\
\hline 12 & 18 & 15 & 16 & 16 \\
\hline 14 & 6 & 4 & 8 & 8 \\
\hline 15 & 2 & 2 & 3 & 8 \\
\hline 16 & 3 & 2 & 1 & 1 \\
\hline 17 & 12 & 13 & 10 & 10 \\
\hline 18 & 13 & 13 & 11 & 10 \\
\hline $19 a$ & 14 & 18 & 18 & 16 \\
\hline $19 b$ & 2 & 3 & 3 & 1 \\
\hline $19 \mathrm{c}$ & 2 & 2 & 5 & 8 \\
\hline Ciprofloxacin & 0.9 & 0.9 & 0.9 & 0.85 \\
\hline
\end{tabular}

\section{RESULTS AND DISCUSSION}

\section{Chemistry}

Thiophene-2-ethyl carboxylate derivative was the key intermediate for the synthesis of a novel series of thieno[3,2-d]pyrimidine and 3-[2-amino-3-cyano-4-phenyl]pyrazolo-5(4-chlorophenyl)-thiophene-2-carboxylic acid derivatives to be screened as anticancer and antibacterial agents. The synthetic route of target compounds 2-13 is illustrated in Schemes 
1 and 2. Commercially available 3-amino-5-(4-chlorophenyl)-thiophene-2-carboxylic acid (1) underwent esterification with ethanol in the presence of $\mathrm{HCl}$ to provide ethyl 3-amino5-(4-chlorophenyl)-thiophene-2-carboxylate (2). The latter was condensed with thiophosgene in dry chloroform stirred under reflux for $5 \mathrm{~h}$ to obtain the corresponding 3 -isothiocyanate 3 . Treatment of compound 3 with sulfa drugs in DMF yielded the corresponding ethyl-5-(4-chlorophenyl)-3-[N-(substituted)-4-(carbamothioyl)amino-benzenesulfonamide] thiophene-2-carboxylate derivatives $\mathbf{4 a - c}$, which underwent intramolecular cyclization by the treatment with hydrazine hydrate to afford the corresponding $N$-aminopyrimidine derivatives 5a-c. Triazolopyrimidine derivatives $6 \mathbf{6}-\mathbf{c}$ were obtained via reaction of compounds 5a-c with aromatic aldehyde, namely, $p$-fluorobenzaldehyde in acetic acid containing sodium acetate. IR and ${ }^{1} \mathrm{H}$ NMR spectra of compounds $6 \mathbf{6}-\mathbf{c}$ revealed disappearance of the $\mathrm{N}$-amino group. Also, treatment of $5 \mathrm{a}-\mathrm{c}$ with formic acid afforded triazolopyrimidine derivatives 7a-c (Scheme 1). 2-Benzyl-6-(4-chlorophenyl)-thieno[3,2- $d$ ]pyrimidine-4-one (8) was obtained via reaction of ethyl 3-amino-5-(4-chlorophenyl) thiophene-2-carboxylate (2) with benzylamine in the presence of triethylorthoformate. Compound 2 underwent cyclization in the treatment with hydrazine hydrate in the presence of triethylorthoformate to afford $\mathrm{N}$-aminopyrimidine derivative $\mathbf{9}$. The structure of<smiles>CCOC(=O)c1sc(-c2ccc(Cl)cc2)cc1[N+](=O)[O-]</smiles>

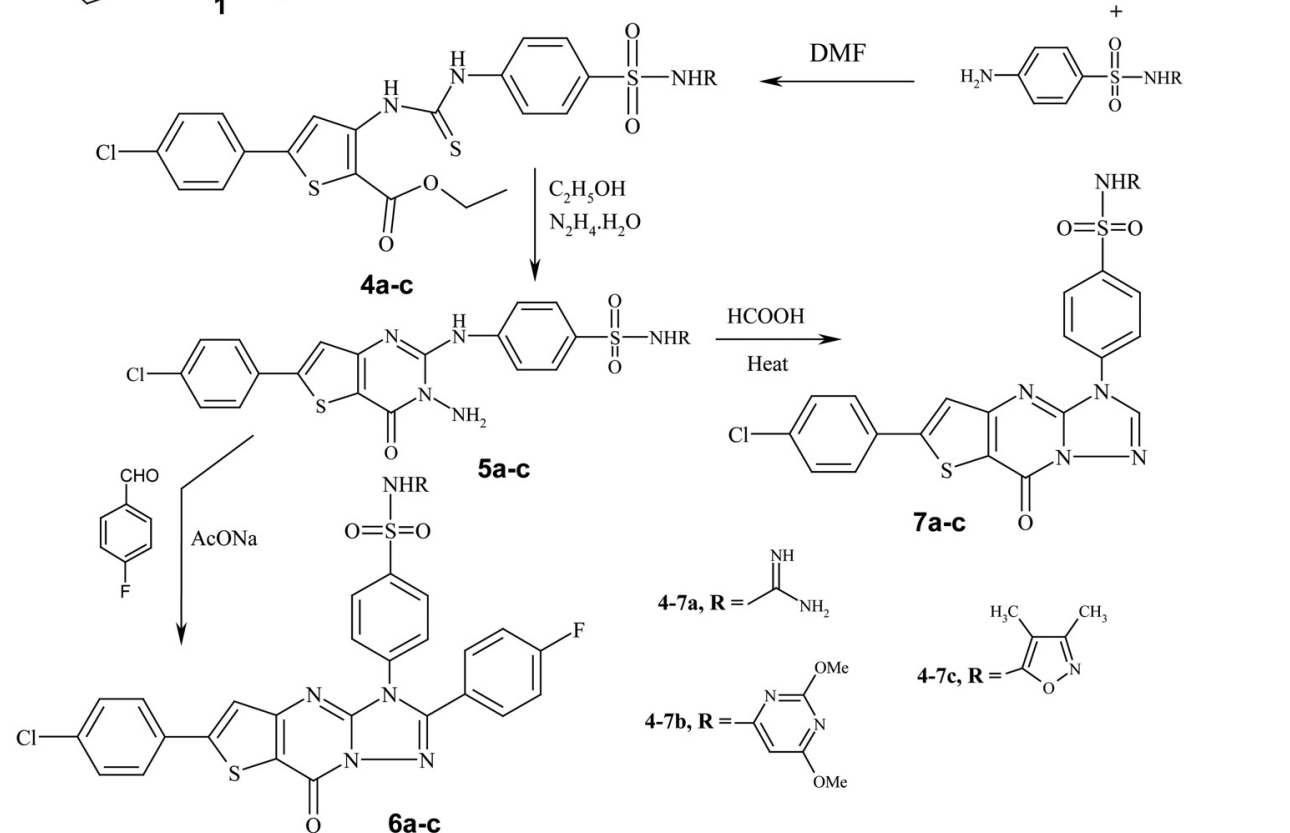

Scheme 1 
compound 9 was confirmed by ${ }^{1} \mathrm{H}$ NMR (DMSO- $\left.d_{6}\right)$, which revealed the absence of triplet and quartet patterns of the ethyl group and appearance of signals at $8.4 \mathrm{ppm}$ for $(1 \mathrm{H})$ pyrimidine. $\mathrm{N}$-aminopyrimidine derivative 9 when reacted with 4-benzylidene-2-phenyl$4 \mathrm{H}$-oxazol-5-one in dry pyridine gave $\mathrm{N}$-imidazole derivative 10. Triazole-thione derivative 11 was prepared by treatment of $\mathrm{N}$-amino pyrimidine derivative 9 with thiourea (29).

Structure of compound $\mathbf{1 1}$ was supported by elemental analysis, IR and ${ }^{1} \mathrm{H}$ NMR spectral data. Its IR spectrum exhibited the absence of $\mathrm{CO}$ band and the presence of $\mathrm{NH}$ band at $3330 \mathrm{~cm}^{-1}$ whereas ${ }^{1} \mathrm{H}$ NMR showed signals at $7.25(\mathrm{~d}, 2 \mathrm{H}, \mathrm{Ar}-\mathrm{H}), 7.50(\mathrm{~d}, 2 \mathrm{H}, \mathrm{Ar}-\mathrm{H})$, 7.80 (s, $\mathrm{CH}$ thiophene), 9.00 (s, $1 \mathrm{H}$, pyrimidine) and $9.4 \mathrm{ppm}\left(\mathrm{s}, 1 \mathrm{H}, \mathrm{NH}, \mathrm{D}_{2} \mathrm{O}\right.$ exchangeable).

Thionation of compound 9 by treatment with $\mathrm{P}_{2} \mathrm{~S}_{5}$ in pyridine gave unexpectedly new bis-6,6'-(4-dichlorophenyl)-thieno[2,3-e]pyrimido[3,4-c][1,2,4,5]tetrazine (12) rather than the expected monothione derivative (13). IR spectrum of compound 12 showed the absence of $\mathrm{NH}_{2}$, while the IR spectrum of compound 13 showed that the $\mathrm{NH}_{2}$ group was still present, in addition to the presence of $C=S$ at $1265 \mathrm{~cm}^{-1}$ (Scheme 2). On repeating the same reaction in xylene, the mono thione derivative (13) was obtained based on the IR data, which showed the presence of $\mathrm{NH}_{2}$ and $\mathrm{C}=\mathrm{S}$ bands. ${ }^{1} \mathrm{H}$ NMR revealed signals at $\delta 5.70 \mathrm{ppm}$ for $\mathrm{NH}_{2}$ and ${ }^{13} \mathrm{C}$ NMR signal at $\delta 166.81 \mathrm{ppm}$ for $\mathrm{C}=\mathrm{S}$. It is important to mention that the new compound 12 was prepared according to known reaction conditions $(24,29)$.

Reaction of 3-amino-5-(4-chlorophenyl)thiophene-2-carboxylic acid (1) with phenacyl bromide furnished 5-(4-chlorophenyl)-3-[(2-oxo-2-phenylethyl)amino)]thiophene-2-carboxylic acid (14), which upon reaction with malononitrile in sodium ethoxide gave pyrrole derivative 15. Compound 15 underwent cyclization upon treatment with acetic anhydride

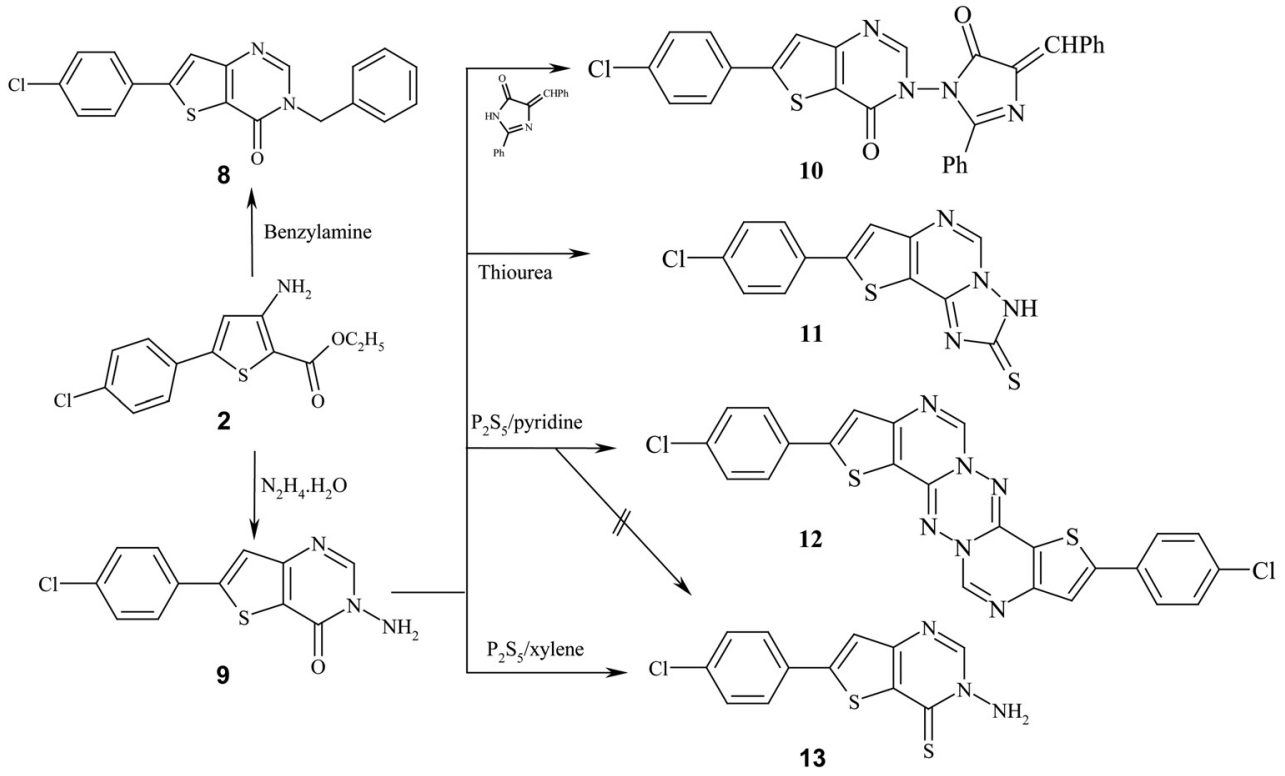

Scheme 2 
for a long time $(12 \mathrm{~h})$ to give the corresponding pyrazolopyrimidine derivative 16 . Under the condition of fusion of compound $\mathbf{1 5}$ with succinic anhydride, compound $\mathbf{1 7}$ was afforded.

Finally, heating of compound $\mathbf{1 5}$ with triethylorthoformate in boiling acetic anhydride gave the ethylpyrroloimidoformate derivative 18. The latter underwent cyclization after treatment with hydrazide derivatives to afford products $19 a-c$ with three fused rings (Scheme 3).

\section{Antitumor activity and structure activity relationship}

The effect of newly synthesized compounds was evaluated through in vitro growth of three human tumor cell lines representing different tumor types, namely, liver cancer (HepG-2), colon cancer (HT-29) and lung cancer (NCI-H460), after continuous exposure for $48 \mathrm{~h}$. The results summarized in Table III show that most of the tested compounds exhibited marked activity compared to doxorubicin. Compounds $16\left(G I_{50}=0.02,0.04\right.$ and 0.06 $\mu \mathrm{mol} \mathrm{L}{ }^{-1}$, resp. $)$ and $19 b\left(G I_{50}=0.02,0.03\right.$ and $0.05 \mu \mathrm{mol} \mathrm{L}{ }^{-1}$, resp. $)$ exhibited higher antican-<smiles>Nc1cc(-c2ccc(Cl)cc2)sc1C(=O)O</smiles><smiles>N#Cc1c(-c2ccccc2)cn(-c2cc(-c3ccc(Cl)cc3)sc2C(=O)O)c1N</smiles><smiles>CCCCC[18O]c1cn(-c2cc(-c3ccc(Cl)cc3)sc2C(=O)O)c(N=COCC)c1C#N</smiles18 17

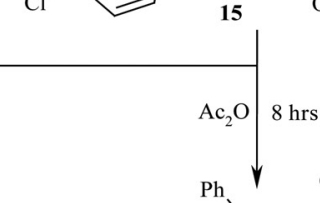<smiles>[R]c1nnc2c3c(-c4ccccc4)cn(-c4cc(-c5ccc(Cl)cc5)sc4C(=O)O)c3ncn12</smiles><smiles></smiles><smiles>[R]C#Cc1ccc(Cl)cc1</smiles>

$\mathrm{c}, \mathrm{R}=$

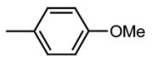

Scheme 3 
cer activity than doxorubicin $\left(G I_{50}=0.04,0.05\right.$ and $0.09 \mu \mathrm{mol} \mathrm{L} \mathrm{L}^{-1}$, resp.) against the three tumor cell lines. Such high activity of both compounds is attributed to the presence of pyrrolopyrimidine moiety at position 3 in the thiophene derivative $\mathbf{1 6}$ but is also due to the presence of triazolopyrimidine moiety as in compound $\mathbf{1 9 b}$. In addition, the presence of stronger electron-withdrawing substituents (chloro) in the para-position of the phenyl ring might be responsible for enhancing the growth inhibition activity.

Compounds 19a and 19c exhibited moderate to good antitumor activity due to the electronic nature of the substituent on the phenyl ring attached to [1,3,4]-triazolyl moiety: in the absence of such substituent as in 19a, moderate inhibition activity was observed, while phenyl with an electron donating group $\left(\mathrm{OCH}_{3}\right)$ attached to the [1,3,4]-triazolyl moiety as in compound 19c was assumed responsible for good activity.

Structure versus activity revealed that, by changing the substituent on C-3 of the thiophene ring, a difference in activity was observed. Compounds $4 \mathbf{b}\left(G I_{50}=0.06,0.09\right.$ and $0.1 \mu \mathrm{mol} \mathrm{L}-1)$ and $15\left(G I_{50}=0.06,0.08\right.$ and $\left.0.1 \mu \mathrm{mol} \mathrm{L}^{-1}\right)$ were almost as active as doxorubicin. This activity may be due to the presence of $\mathrm{N}$-(2,6-dimethoxypyrimidin-4-yl)-benzenesulfonamide moiety at position 3 in the thiophene derivative $4 \mathbf{b}$ and aminopyrrole moiety attached to the thiophene ring in $\mathbf{1 5}$. Compounds $5 \mathbf{a}, \mathbf{b}, \mathbf{6 b}$ and $\mathbf{1 1}$ exhibited good to moderate inhibition activities with $G I_{50}$ ranging from 0.4 to $3.2 \mu \mathrm{mol} \mathrm{L}^{-1}$; activity of these compounds is probably due to the presence of a substituent in the phenyl ring attached to thieno[3,2- $d]$ pyrimidine such as ( $N$-carbamimidoyl and $N$-pyrimidinyl) benzenesulfonamide in $\mathbf{5 a}, \mathbf{b},[1,2,4]$ triazolopyrimidine attached to $p$-fluorophenyl in $\mathbf{6} \mathbf{b}$ and thioxotriazole moiety fused with the pyrimidine ring in 11. Furthermore, compounds $4 \mathbf{a}, 5 \mathbf{c}, \mathbf{6 a}, \mathbf{c}$, 9, 10, 14, 17 and 18 exhibited moderate to low antitumor activity on the three tumor cell lines, while compounds $\mathbf{4 c}$ and $\mathbf{1 2}$ exhibited very low antitumor activity.

\section{Antibacterial activity}

Compounds 4a-c, 5a-c, 6a-c, 8-12 and 14-19 were also tested for antibacterial activity (Table IV). The antibacterial data indicated that triazolopyrimidine derivatives $\mathbf{6 b}$ and $\mathbf{1 9 b}$ were the most active compounds, with MIC values of $1-3 \mu \mathrm{mol} \mathrm{L}^{-1}$ against Gram-positive and Gram-negative bacteria, comparable to the standard drug ciprofloxacin $(M I C=0.9$ $\left.\mu \mathrm{mol} \mathrm{L}{ }^{-1}\right)$. Such high activity may be due to the presence of triazolopyrimidine fused with the thiophene ring, in addition to the presence of 4-fluorophenyl in $\mathbf{6 b}$ and 4-chlorophenyl in $19 \mathrm{~b}$ attached to the triazolopyrimidine.

Also, compounds $4 b, 15$ and $19 c$ were the most active ones against all bacterial strains except Salmonella typhi, with MIC values of $2-5 \mu \mathrm{mol} \mathrm{L}^{-1}$. The activity of these compounds may be attributed to the presence of $N$-(2,6-dimethoxypyrimidin-4-yl)-benzenesulfonamide moiety attached to the thiophene ring in $4 \mathrm{~b}$, pyrrolo moiety attached to the thiophene ring in 15 and triazolopyrimidine structure in 19c. Furthermore, pyrrolo[2,3- $d$ ]pyrimidine attached to $\mathrm{C} 3$ of the thiophene in compound 16 exhibited high activity, with MIC values of $1-3 \mu \mathrm{mol} \mathrm{L} \mathrm{L}^{-1}$ against all bacterial strains. Antibacterial activity of compounds 8-10 increased in dependence on the way of cyclization of the thiophene amino ester derivative 2 . Compound 10 exhibited high activity against all Gram-positive and Gram-negative bacteria with MIC 2-4 $\mu \mathrm{mol} \mathrm{L}^{-1}$, while compounds 8 and 9 exhibited promising activity against all strains. This activity may be attributed to the presence of $N$-imidazole moiety at pyrimidine in 10, $\mathrm{N}$-benzyl group in compound 8 and $\mathrm{N}$-amino group at pyrimidine in compound 9. 
Compounds $4 \mathbf{a}, \mathbf{5 a - c ,}$ 6a,c, 11 and $\mathbf{1 4}$ showed promising activity against all the tested bacteria, and this activity may be due to the presence of imido group in $4 \mathbf{a}$, the formation of fused $\mathrm{N}$-amino-thienopyrimidine skeleton as in $\mathbf{5 a - c}$, in addition to the presence of $[1,2,4]$ triazolopyrimidine in $\mathbf{6 a - c}$ and $[1,2,4]$ triazolopyrimidine in 11. Also, the presence of oxo-phenylethylamino attached to the thiophene ring in 14 seems to increase the antibacterial activity. Moreover, compound $4 \mathrm{c}$ exhibited good activity against Gram-negative bacteria with MIC of $4 \mu \mathrm{mol} \mathrm{L}^{-1}$ and moderate activity against Gram-positive bacteria, while compounds 12, 17, 18 and 19a displayed low activity against all the tested bacteria.

\section{CONCLUSIONS}

In the present work, we synthesized some novel thiophenes bearing sulfonamide, pyrrole, pyrrolopyrimidine structures, and thieno[3,2- $d]$ pyrimidine derivatives containing 1,2,4-triazole moiety, and investigated their anticancer and antibacterial activity. Among the synthesized compounds, 5-(4-chlorophenyl)-3-(2-methyl-4-oxo-5-phenyl-3,4dihydro-7H-pyrrolo[2,3-d]pyrimidine-7-yl)-thiophene-2-carboxylic acid (16) and 5-(4-chlorophenyl)-\{3-(4-chlorophenyl)-9-phenyl-7H-pyrrolo[3,2-e][1,2,4]triazolo[4,3-c]-pyrimidin-7-yl\}-thiophene-2-carboxylic acid (19b) exhibited higher anticancer activity than doxorubicin. Furthermore, compounds ethyl 5-(4-chlorophenyl)-3-[N-(2,6-dimethoxypyrimidin-4-yl)-4-(carbamothioyl) amino-benzenesulfonamide]thiophene-2-carboxylate (4b) and 3-(2-amino-3-cyano-4-phenyl-1H-pyrrol-1-yl)-5-(4-chlorophenyl)-thiophene-2-carboxylic acid (15) exhibited growth inhibition activity nearly as high as that of doxorubicin.

Compounds 4b, 15 and 19b also exhibited good antibacterial activity against Grampositive and Gram-negative bacteria along with 5-(4-chlorophenyl)-\{3-(4-methoxyphenyl)9-phenyl-7H-pyrrolo[3,2-e][1,2,4] triazolo[4,3-c]-pyrimidin-7-yl\}-thiophene-2-carboxylic acid (19c), 7-(4-chlorophenyl)-2-(4-fluorophenyl)-1-(N-(2,6-dimethoxypyrimidin-4-yl) benzenesulfonamide thieno[3,2- $d][1,2,4]$ triazolo[1,5-a]pyrimidine-5(1H)-thione $(6 \mathbf{b})$ and 6-(4-chlorophenyl)-3-(5-benzylidene-2-phenyl-3,5-dihydro-4H-imidazol-4-one-3-yl) thieno[3,2-d]pyrimidin-4(3H)-one (10).

Activities of these compounds were strongly dependent on the basic skeleton of the molecules and the nature of the heterocyclic ring attached to the thiophene unit as well as on the nature of the substituent at the thiophene unit.

Acknowledgments. - The authors are grateful to the Micro-analytical Unit, Cairo University, Egypt, for micro-analytical data, IR, NMR and mass spectra. The authors are also grateful to the staff of the Antitumor Laboratory, the National Cancer Institute, Cairo University, Egypt, and Fermentation Biotechnology and Applied Microbiology (Ferm-BAM) Center, Al-Azhar University, Faculty of Science, Cairo, Egypt. The authors extend their sincere appreciation to the Deanship of Scientific Research at the Al-Imam Mohammad Ibn Saud Islamic University for the funding of this research through the Research Group Project no. 341212.

\section{REFERENCES}

1. H. N. Hafez and A. B. A. El-Gazzar, Design and synthesis of 3-pyrazolyl-thiophene, thieno[2,3-d] pyrimidines as new bioactive and pharmacological activities, Bioorg. Med. Chem. Lett. 18 (2008) 5222-5227; DOI: 10.1016/j.bmcl.2008.08.071. 
2. S. Abbas, M. Hussain, S. Ali, M. Parvez, A. Raza, A. Haider and J. Iqbal, Structural, enzyme inhibition, antibacterial and DNA protection studies of organotin(IV) derivatives of thiophene-2carboxylic acid, J. Organomet. Chem. 724 (2013) 255-261; DOI: 10.1016/j.jorganchem.2012.11.033.

3. Y. Ni. A. Gopalsamy, D. Cole, Y. Hu, R. Denny, M. Lpek, J. Liu, J. Lee, J. P. Hall, M. Luong, J. B. Telliez and L. L. Lin, Identification and SAR of a new series of thieno[3,2-d]pyrimidines as Tpl2 kinase inhibitors, Bioorg. Med. Chem. Lett. 21 (2011) 5952-5956; DOI: 10.1016/j.bmcl.2011.07.069.

4. T. P. Heffron, M. Berry, G. Castanedo, C. Chang, I. Chuckowree, J. Dotson, A. Folkes, J. Gunzner, J. D. Lesnick, C. Lewis, S. Mathieu, J. Nonomiya, A. Olivero, J. Pang, D. Peterson, L. Salphati, D. Sampath, S. Sideris, D. P. Sutherlin, V. Tsui, N. C. Wan, S. Wang, S. Wong and B. Y. Zhu, Identification of GNE-477, a potent and efficacious dual PI3K/mTOR inhibitor, Bioorg. Med. Chem. Lett. 20 (2010) 2408-2411; DOI: 10.1016/j.bmcl. 2010.03.046.

5. Q. Tan, Z. Zhang, J. Hui, Y. Zhao and L. Zhu, Synthesis and anticancer activities of thieno [3,2-d] pyrimidines as novel HDAC inhibitors, Bioorg. Med. Chem. 22 (2014) 358-365; DOI: 10. 1016/ j.bmc. 2013.11.021.

6. J. Kim, J. Kwon, D. Lee, S. Jo, O. Dongsik, C. Jihyun, E. Park, J. Y. Hwang, Y. Ko, I. Choi, M. K. Ju, J. Ahn, J. Kim, S.-J. Han, T.-H. Kim, J. Cechetto, J. Nam, S. Ahn, P. Sommer, M. Liuzzi and J. Lee, Serendipitous discovery of 2-((phenylsulfonyl)methyl)-thieno[3,2-d]pyrimidine derivatives as novel HIV-1 replication inhibitors, Bioorg. Med. Chem Lett. 24 (2014) 5473-5477; DOI: 10.1016/j. bmcl.2014.10.007.

7. K. W. Temburnikar, S. C. Zimmermann, N. T. Kim, C. R. Ross, C. Gelbmann, C. E. Salomon, G. M. Wilson, J. Balzarini and K. L. Seley-Radtke, Antiproliferative activities of halogenated thieno[3,2d] pyrimidines, Bioorg. Med. Chem. 22 (2014) 2113-2122; DOI: 10.1016/j. bmc.2014.02.033.

8. A. J. Folkes, K. Ahmadi, W. K. Alderton, S. Alix, S. J. Baker, G. Box, I. S. Chuckowree, P. A. Clarke, P. Depledge, S. A. Eccles, L. S. Friedman, A. Hayes, T. C. Hancox, A. Kugendradas, L. Lensun, P. Moore, A. G. Olivero, J. Pang, S. Patel, G. H. Pergl-Wilson, F. I. Raynaud, A. Robson, N. Saghir, L. Salphati, S. Sohal, M. H. Ultsch, M. Valenti, H. J. A. Wallweber, N. C. Wan, C. Wiesmann, P. Workman, A. Zhyvoloup, M. J. Zvelebil and S. J. Shuttleworth, The identification of 2-(1H-indazol-4-yl)6-(4-methanesulfonyl-piperazin-1-ylmethyl)-4-morpholin-4-yl-thieno[3,2- $d$ ]pyrimidine (GDC0941) as a potent, selective, orally bioavailable inhibitor of class I PI3 kinase for the treatment of cancer, J. Med. Chem. 51 (2008) 5522-5532; DOI: 10.1021/jm800295d.

9. K. A. Chakraborti, B. Gopalakrishnan, M. E. Sobhia and M. Alpeshkumar, 3D-QSAR studies on thieno [3,2-d] pyrimidines as phosphodiesterase IV inhibitors, Bioorg. Med. Chem. Lett. 13 (2003) 1403-1408; DOI: 10.1016/ S0960-894X(03)00172-0.

10. H. N. Hafez, H. A. R. Hussein and A. B. A. El-Gazzar, Synthesis of substituted thieno[2,3-d]pyrimidine-2,4-dithiones and their S-glycoside analogues as potential antiviral and antibacterial agents, Eur. J. Med. Chem. 45 (2010) 4026-4034; DOI: 10.1016/j.ejmech.2010.05.060.

11. H. N. Hafez, A. B. A. El-Gazzar and M. E. A. Zaki, Simple approach to thieno[3,2-d]-pyrimidines as new scaffolds of antimicrobial activities, Acta Pharm. 66 (2016) 331-351; DOI: 10.1515/acph-20160029.

12. H. N. Hafez, A. B. A. El-Gazzar and G. A. M. Nawwar, Synthesis, biological and medicinal significance of S-glycosido-thieno[2,3-d]-pyrimidines as new anti-inflammatory and analgesic agents, Eur. J. Med. Chem. 45 (2010) 1485-1493; DOI: 10.1016/j.ejmech.2009. 12.056.

13. H. N. Hafez and A. B. A. El-Gazzar, Design and synthesis of 3-pyrazolyl-thiophene, thieno[2,3- $d]$ pyrimidines as new bioactive and pharmacological activity, Bioorg. Med. Chem. Lett. 18 (2008) 5222-5227; DOI: 10.1016/j.bmcl.2008.08.071.

14. Z. Liu, S. Wu, Y. Wang, R. Li, J. Wang, L. Wang, Y. Zhao and P. Gong, Design, synthesis and biological evaluation of novel thieno[3,2-d] pyrimidine derivatives possessing diaryl semicarbazone scaffolds as potent antitumor agents, Eur. J. Med. Chem. 87 (2014) 782-793; DOI: 10.1016/j.ejmech.2014.10.022. 
15. M. E. Welker and G. R. Kulik, Synthesis of PI3K/Akt/mTOR signaling pathway inhibitors, Bioorg. Med. Chem. 21 (2013) 4063-4091; DOI: 10.1016/ j.bmc. 2013.04.083.

16. E. Perspicace, V. Jouan-Hureaux, R. Ragno, F. Ballante, S. Sartini, C. La Motta, F. Da Settimo, B. Chen, G. Kirsch, S. Schneider, B. Faivre and S. Hesse, Design, synthesis and biological evaluation of new classes of thieno[3,2- $d]$ pyrimidinone and thieno[1,2,3]triazine as inhibitor of vascular endothelial growth factor receptor-2 (VEGFR-2), Eur. J. Med. Chem. 63 (2013) 765-781; DOI: 10.1016/j. ejmech. 2013.03.022.

17. T. R. Rheault, T. R. Caferro, S. H. Dickerson, K. H. Donaldson, M. D. Gaul, A. S. Goetz, R. J. Mullin, O. B. McDonald, K. G. Petrov, D. W. Rusnak, L. M. Shewchuk, G. M. Spehar, A. T. Truesdale, D. E. Vanderwall, E. R. Wood and D. E. Uehling, Thienopyrimidine-based dual EGFR/ErbB-2 inhibitors, Bioorg. Med. Chem. Lett. 19 (2009) 817-820; DOI: 10.1016/j.bmcl.2008.12.011.

18. G. C. Tron, T. Pirali, R. A. Billington, P. L. Canonico, G. Sorba and A. A. Genazzani, Click chemistry reactions in medicinal chemistry: Applications of the 1,3-dipolar cycloaddition between azides and alkynes, Med. Res. Rev. 28 (2008) 278-308; DOI: 10.1002/med.20107.

19. J. A. Demaray, J. E. Thuener, M. N. Dawson and S. Sucheck, Synthesis of triazole-oxazolidinones via a one-pot reaction and evaluation of their antimicrobial activity, J. Bioorg. Med. Chem. Lett. 18 (2008) 4868-4871; DOI: 10.1016/j.bmcl.2008.07.087.

20. J. Wu, N. Green, R. Hotchandani, Y. Hu, J. Condon, A. Huang, N. Kaila, H. Q. Li, S. Guler, W. Li, S. Y. Tam, Q. Wang, J. Pelker, S. Marusic, S. Hsu, J. P. Hall, J. B. Telliez, J. Cui and L. L. Lin, Selective inhibitors of tumor progression loci-2 (Tpl2) kinase with potent inhibition of TNF-a production in human whole blood, Bioorg. Med. Chem. Lett. 19 (2009) 3485-3488; DOI: 10.1016/j.bmcl.2009.05.009.

21. C. Gill, G. Jadhav, M. Shaikh, R. Kale, A. Ghawalkar, D. Nagargoje and M. Shiradkar, Clubbed[1,2,3] triazoles by fluorine benzimidazole: A novel approach to H37Rv inhibitors as a potential treatment for tuberculosis, Bioorg. Med. Chem. Lett. 18 (2008) 6244-6247; DOI: 10.1016/j.bmcl.2008.09.096.

22. M. M. Kamel and N. Y. Megally Abdo, Synthesis of novel 1,2,4-triazoles, triazolothiadiazines and triazolothiadiazoles as potential anticancer agents, Eur. J. Med. Chem. 86 (2014) 75-80; DOI: 10.1016/j.ejmech. 2014.08.047.

23. Y. P. Hou, J. Sun, Z. H. Pang, P. C. Lv, D. D. Li, L. Yan, H. J. Zhang, E. X. Zheng, J. Zhao and H. L. $\mathrm{Zhu}$, Synthesis and antitumor activity of 1,2,4-triazoles having 1,4-benzodioxan fragment as a novel class of potent methionine aminopeptidase type II inhibitors, Bioorg. Med. Chem. 19 (2011) 5948-5954; DOI: 10.1016/j.bmc.2011.08.063.

24. H. Wamhoff, M. Ertas and S. M. S. Atta, Notizen heterocyclic $\beta$-enamino esters, 39. Synthesis of 1H-pyrazolo[3,4-d]pyrimidines, Liebigs Ann. Chem. 9 (1985) 1910-1916; DOI: 10.1002/ jlac.198519850918.

25. P. Skehan, R. Storeng, D. Scudiero, A. Monks, J. McMahon, D. Vistica, J. T. Warren, H. Bokesch, S. Kenny and M. R. Boyd, New colorimetric cytotoxicity assay for anti-cancer drug screening, J. Natl. Cancer Inst. 82 (1990) 1107-1112; DOI: 10.1093/jnci/82.13.1107.

26. A. Monks, D. Scudiero, P. Skehan, R. Shoemaker, K. Paul, D. Vistica, C. Hose, J. Langley, P. Cronise, A. Vaigro-Wolff, M. Gray-Goodrich, H. Campbell, J. Mayo and J. M. Boyd, Feasibility of a highflux anticancer drug screen using a diverse panel of cultured human tumor cell lines, J. Natl. Cancer Inst. 83 (1991) 757-766; DOI: 10.1093/ jnci /83.11.757.

27. M. J. Weinstein and G. H. Wagman, Plant-derived Antibiotics, in Antibiotics Isolation, Separation and Purification (Ed. L. A. Mitscher), Elsevier, Amsterdam 1978, p. 464.

28. H. Naeimi, Z. S. Nazifi, S. M. Amininezhad and M. Amouheidari, Synthesis, characterization and in vitro antimicrobial activity of some new Schiff bases and their complexes, J. Antibiot. 66 (2013) 687-689; DOI: 10.1038/ja.2013.73.

29. P. G. Baraldi, H. El-Kashef, A. Farghaly, P. Vanelle and F. Fruttarolo, Synthesis of new pyrazolo[4,3e]-1,2,4-triazolo[1,5-c]pyrimidines and related heterocycles, Tetrahedron 60 (2004) 5093-5104; DOI: 10.1016/j.tet.2004.04.010. 